\title{
THE PHYSICIAN, THE LAW, AND THE DRUG ABUSER
}

\section{WIIJAMM C. WHITFORD $\dagger$}

The rapid expansion of illegal drug use, particularly among white middle and upper class youth, has induced governments at all levels to review their laws and policies regarding drug abuse. In many cases these reviews have produced policy changes resulting in less exclusive reliance on the traditional punitive, or law-enforcement, approach to drug abuse problems, and greater reliance on a balanced approach which increases the emphasis on treatment and rehabilitation of illegal drug users. ${ }^{1}$ For example, many states have now reduced the first conviction for use or possession of marijuana to a misdemeanor ${ }^{2}$ and consciously encourage probation and other rehabilitation-oriented sentences. The Nixon administration after initially advocating increased penalties for drug law violations later supported federal legislation, ${ }^{3}$ now enacted,

+ Associate Professor of Iaw, University of Wisconsin, B.A. 1961, University of Wisconsin; LL.B. 1964, Yale University. Member, District of Columbia Bar. The author expresses his appreciation to Raymond Thoenig for his help in the research for this Article.

I See generally W. ElDRIDGe, Narcotics and the LAW (2d ed. rev. 1967); A. Lindesmitth, The AdDict and the Law (1965) ; President's Advisory Conarission on Narcotic and Drug Abuse, Finai Report (1963) (Prettyman Commission); Task Force on Narcotics and Drug Abuse, President's Conimission on Law Enforcement aNd ADMinistration of Justice, TAsk Force Report: Narcotics and Drug Abuse (1967) [hereinafter cited as TASK Force Report].

Treatment and rehabilitation of the drug abuser can, of course, mean different things to different people. For example, many states advertise involuntary civil commitment programs for narcotics addicts as an approach emphasizing rehabilitation rather than punishment; yet some commentators dispute this claim. See A. LINDESMITH, supra, 290-94. Certainly a treatment and rehabilitation emphasis is attributed to the new statutory schemes for placing the accused drug law violator under supervised probation, note 5 infra \& accompanying text. Others contend that only "ambulatory" treatment of narcotics addicts, by which a physician prescribes maintenance doses of the addicting drug while helping the addict cope with the social or medical problem that led to addiction, can produce rehabilitation. See A. LINDESMITH, supra, passim; King, The Narcotics Bureau and the Harrison Act: Jailing the Healers and the Sick, 62 Y ALE L.J. 736 (1953). Most persons would probably agree at least that no single rehabilitative approach will work well for all kinds of drug abusers. See Cole, Report on the Treatment of Drang Addiction, in TASK FORCE REPORT, supra, 135. This Article will assume that "treatment and rehabilitation" approaches to drug abuse include all approaches with the goal of cessation or restriction of drug abuse through medical treatment or counseling of the drug abuser rather than through deterrence effected by criminal sanctions. (1958).

2 See, e.g., Wrs. Stat. Ann. $\$ \$ 161.30(12)$ (a), 973.02 (Supp. 1971) ; id. $\S 939.60$

3 S. 2637, 91st Cong., 1st Sess. (1969); see 1969 Cong. Q. Armanac 57-A (Presidential message to Congress). In subsequent testimony before the Senate Committee on the Judiciary, John E. Ingersoll, Director of the Bureau of Narcotics and Dangerous Drugs, announced that the Administration had changed its view and was prepared to support legislation eliminating minimum sentences for nearly all first offenses. Id. 710 . 
which makes the first conviction for use or possession of any illegal drug a misdemeanor and largely eliminates minimum sentences for all drug offenses. ${ }^{4}$ This legislation also permits probation and similar sentencing dispositions when the judge believes rehabilitation is a realistic objective. ${ }^{5}$ Complementing this change in statutory penalties, some law enforcement agencies are now concentrating their efforts on detection and arrest of large volume sellers rather than users and small-time peddlers, usually also chronic drug users. ${ }^{6}$

Other policy changes reflecting increased emphasis on treatment and rehabilitation of drug abusers tend to conflict with maintenance of penal sanctions for illegal drug use. For example, government financial support is being given to medical and counseling programs aimed at treating and rehabilitating the chronic drug abuser without exposing him to criminal sanction. ${ }^{7}$ In a number of cities law enforcement officials have sanctioned medically supervised methadone maintenance programs which aim to enable the narcotics abuser to cope better with his environment without eliminating drug use itself. ${ }^{8}$ Going even further, a few politicians are now discussing the legalization of marijuana, and lawyers are trying to obtain greater protection for users through the courts. ${ }^{10}$

While the limits of this trend are yet unclear, the conflicts are certain to grow as new programs and laws proliferate. And unless the two approaches are to undercut one another, perhaps dooming the newer one, serious attention must be paid to rationalizing their differences and making appropriate adjustments. This Article will focus on

4 Comprehensive Drug Abuse Prevention and Control Act of 1970, Pub. L. No. 91-513, tit. II, pt. D, $\$ \$ 401-11,84$ Stat. 1260 (codified at 21 U.S.C.A. $\$ \$ 841-51$ (Supp. 1971)).

5 For the first possession offense, if the defendant pleads or is found guilty, the judge may defer entry of judgment, with the defendant's consent, and place the defendant on probation of up to one year. On the defendant's satisfactory completion of probation, the original charge is dropped. Id. $\$ 404$ (b) (1), 21 U.S.C.A. $\$ 844$ (b) (1) (Supp. 1971); see id. $\$ 404$ (b) (2), 21 U.S.C.A. $\$ 844($ b) (2) (Supp. 1971) (expunging arrest record of minor discharged under the probation provision).

6 Staff of Senate Comm. on the District of Colvmbia, 91st Cong., 1st Sess., Drug Abuse in the Washington Area 16-28 (1969).

7 Id. 28-33; see Community Mental Health Centers Act $\$ \$ 251-54,42$ U.S.C. $\S \S 2688 \mathrm{k}-n$ (Supp. V, 1970) ; Narcotic Addict Rehabilitation Act of 1966 tits. III, IV 42 U.S.C. \$\$3411-26, 3441 ' (Supp. V, 1970). The President recently reemphasized that the government favors treatment programs for narcotics addicts, presumably without threat of criminal prosecution. N.Y. Times, June 2, 1971, at 24, col. 1 (city ed.).

8 Cole, supra note 1 , at 135; Note, Methadone Maintenance for Heroin Addicts, 78 YALE L.J. 1175 (1969).

9 See, e.g., R. Ciark, CrinIe in America 85-100 (1970).

10 See, e.g., Leary v. United States, 383 F.2d 851 (5th Cir. 1967), rew'd, 395 U.S. 6 (1969), See also Town, Privacy and the Marijuana Lazes, in THE NEw SocIal Drug 118 (D. Smith ed. 1970), \& cases cited therein; Weiss \& Wizner, Pot, Prayer, Politics, and Privacy: The Right to Cut Your Orm Throat in Your Own Way, 54 Iowa I. Rev. 709 (1969). 
one aspect of this emerging conflict: those laws which do or may inhibit drug abusers from contacting physicans about their medical and psychological problems. It will suggest particular changes which should be implemented if the treatment and rehabilitation approach is to be as successful as possible and will consider the extent to which adoption of these changes would hinder implementation of other policies with regard to drug abuse-in particular, policies reflecting a lawenforcement approach.

There are a number of reasons drug abusers need to consult physicians for treatment and, hopefully, rehabilitation. A "bad trip" can cause so much anxiety or (rarely) such destructive conduct that the user requires sedation, which should be administered by physicians because of the possibility of adverse side effects. Drug users who "mainline"- that is, inject the drug directly into the vein -often suffer from serious diseases, such as hepatitis, transmitted by unsterile hypodermic needles. Chronic users of methamphetamine ("speed") and other drugs often suffer from malnutrition more readily recognized in its incipient phases by physicians than laymen. A user dependent on heroin or similar drugs often needs medical supervision if he goes through the painful process of withdrawing from the drug. ${ }^{11}$ Finally, and perhaps most importantly to a policy of treatment and rehabilitation for drug abuse, serious and habitual drug abuse usually indicates underlying personality disturbance or inadequate social adjustment, and no rehabilitation program aiming at cessation of drug use can succeed unless it helps the drug abuser cope with his disturbance or maladjustment. ${ }^{12} \mathrm{~A}$ doctor is frequently in a position to provide appropriate counseling assistance in these circumstances or to refer a patient to a

11 See generally Smith, Luce, \& Dernburg, The Health of Haight-Ashbary, 7 Transaction, Apr. 1970, at 35; Smith \& Rose, Observations in the Haight-Ashbury Medical Clinic of San Francisco, 7 Clinical Pediatrics 313 (1968).

12 For narcotics addiction, the best evidence of this statement is the high rate of readdiction among those who have undergone withdrawal with no accompanying counseling or aftercare. Withdrawal treatment which includes counseling and aftercare usually achieves a substantially lower readdiction rate. L. KoLB, DRUG ADDICTION: A MEdCAL PROBLEM (1962); A. Lindesmith, supra note 1, at 269-302; Cole, supra note 1 , at 138 . Until recently, nearly all of the writing in this area concerned treatment of narcotics addiction only. Two articles discussing treatment and rehabilitation of habitual users of hallucinogenic drugs have suggested that most such users have no personality traits considered abnormal within their subculture; treatment aimed at withdrawal from use of such drugs may require a willingness on the part of the user to leave the subculture. Short of that, medical treatment is needed only for acute reactions to drug use, typically resulting from use of impure drugs. Smith, Changing Drug Patterns in the Haight-Ashbury, 110 CAL. MEDICINE 151, 155-56 (1969); Smith, Use of LSD in the Haight-Ashbury, 110 CAL. MEDICINE 472 (1969). Finally, some evidence, not yet accepted as conclusive, suggests that even chronic tuse of marijuana has no harmful medical effects and may not indicate any psychiatric disturbance or social maladjustment. THe MaruHuaNA PAPERS (D. Solomon ed. 1966); THE NEW Soctal Drug, supra note 10 . If this is correct, from a medical point of view a treatment approach could not have as a meaningful goal patient abstinence from marijuana. 
person or institution that can provide it. And many persons find it easier or more socially acceptable to approach a physician about drug abuse problems, perhaps in conjunction with other medical treatment, than a psychologist, professional counselor, or other person or institution specializing in drug abuse problems. ${ }^{13}$

Partly to meet these needs in communities where a large percentage of drug users reside, a few doctors have established clinics, the most famous and successful of which is probably the Haight-Ashbury Free Medical Clinic in San Francisco. ${ }^{14}$ One of the first problems these clinics have faced has been a lack of rapport between their intended clients and the medical profession. The organizers have discovered that drug users shun established medical facilties, because they fear both overt social disapproval by doctors and hospital personnel and the adverse use, in a criminal proceeding or in some other way, of the information they give doctors and hospital personnel about their drug use. $^{15}$ Indeed, these fears are not groundless. Even today, some doctors and hospitals report drug users to the police, apparently out of either a feeling of social duty or a desire to discourage such individuals from requesting their services. ${ }^{16}$ To overcome these fears, clinics hos-

13 See Maryland Common to Study Problens of Drug Addictron, Drug Abuse STUdy 343-49 (1969) (county schools, some staffed with professional counselors, reported almost no incidence of drug abuse, while $38 \%$ of the same counties' physicians reported about 100 cases of student drug abuse within a one year period).

Drug abusers should be encouraged to consult professional counselors as well as physicians. It may therefore be desirable to protect the confidentiality of communications made by drug abusers to such persons. In general, the present law protects such communications considerably less than communications to physicians. This Article, however, focuses exclusively on physician-patient communications.

14 See generally Smith, Luce, \& Dernburg, supra note 11.

15 [T] hese [establishment] physicians appear unwilling to attempt to solve the local [drug subculture's] health problems. Like many policemen, the public health representatives seem to look on young drug-abusers as subhuman. When adolescents come to Park Emergency [in San Francisco] for help the doctors frequently assault them with sermons, report them to the police or submit them to complicated and drawn-out referral procedures that only intensify their agony. The nurses sometimes tell prospective patients to take their problems elsewhere. The ambulance drivers simply "forget" calls for emergency assistance . . . .

Given this attitude, it is hardly surprising that the adolescents are as frightened of public health officials as they are of policemen. Some would sooner risk death than seek aid at Park Emergency ... . . Many merely live with their symptoms, doctor themselves with home remedies or narcotize themserves to relieve their pain. These young people do not trust "straight" private physicians, who they assume will overcharge them and hand them over to the law.

Id. 38; see Maryland Comm'n to Study Problems of Drug Addiction, supra note 13, at 133-39:

[Large numbers of] addicts tend to stay away from hospitals .... Moreover, when possible, they tend to hide the true nature of their complaint if they are forced to use a hospital emergency room.

16 Hearings on Inquiry into the Problem of Alcoholism and Narcotics Before the Special Subcomm. on Alcoholism \& Narcotics of the Senate Comm. on Labor \& Public Welfare, 91st Cong., 2d Sess., pt. 5, at 983 (1970); Madison Kaleidoscope, Feb. 19, 1970, at 3, col. 3 . 
pitable to drug users have necessarily taken extraordinary measures to provide a friendly environment and insure confidentiality of communications.

The experiences of clinics like the Haight-Ashbury Free Medical Clinic indicate that if such efforts to provide medical services to drug users are to succeed, the client community needs assurance that the information they give the doctors will not be used to the patients' disadvantage. This assurance cannot realistically be given, however, without a number of changes in federal and state law.

Because the penal laws pertaining to drug abuse are administered in several kinds of proceedings at several levels of government and overlap extensively, no single change can eliminate this risk. Those laws suggesting the greatest potential for deterring resort to medical help will be discussed here, but because a threat may be perceived simultaneously from several quarters the incremental effect of any one of the changes to be proposed may not immediately appear substantial. Nevertheless, the elimination of legal deterrents to requests for treatment and rehabilitation is important, and, if each authority assumes the responsibility for removing the deterrent caused by its laws, the benefits to be gained from a fully implemented rationalization of the drug abuse laws may be substantial.

\section{Federal Law}

Three aspects of federal law should be changed or clarified if the confidentiality of physician-patient communications concerning drug abuse is to be fully protected. The first concerns the status of a physician-patient testimonial privilege in federal court proceedings. A significant but not altogether desirable proposal which would affect the federal law governing the physician-patient privilege is the revised draft of the Proposed Rules of Evidence for the United States Courts and Magistrates. ${ }^{17}$ The second concerns the investigatory powers granted to the Attorney General by the Comprehensive Drug Abuse Prevention and Control Act of $1970 .{ }^{18}$ The third concerns the availability to federal officials of certain records which regulations issued by

1751 F.R.D. 315 (1971) [hereinafter cited as Revised Proposed Rules]. Approved by the Judicial Conference of the United States in October 1970 and then submitted to the Supreme Court for approval and promulgation, 18 U.S.C. \$ 3771 (Supp. V, 1970) ; 28 U.S.C. $\$ 2072$ (Supp. V, 1970), amending id. (1964), the proposed rules were returned by the Court to the Judicial Conference in March 1971 "for further consideration." The Conference's Committee on Rules of Practice and Procedure has informally indicated that the reason for the Court's action was that the revised draft of the rules, unlike the preliminary draft, had never been published, depriving the legal community of the opportunity to submit comments and suggestions. The Committee has invited comments on the revised draft.

18 Pub. L. No. 91-513, 84 Stat. 1236, 21 U.S.C.A. \$\$801-966 (Supp. 1971). 
the Food and Drug Administration require of all methadone maintenance programs. ${ }^{19}$

\section{A. The Need for a Limited Federal Physician-Patient Privilege}

Under current federal law the rules of evidence applicable in the United States District Courts vary with the state in which the court sits and the nature of the case. In civil cases the Federal Rules of Civil Procedure prescribe admission of evidence when either a federal statute or rule of evidence or a state rule of evidence applicable in a state court of general jurisdiction would admit it. ${ }^{20}$ Thus, if a doctor-patient privilege is abrogated by any of these three, it need not now be recognized in federal civil cases. The importance of a doctor-patient privilege in drug abuse cases lies, however, mainly in the criminal area. In such cases the Federal Rules of Criminal Procedure seem to require that admissibility be governed exclusively by federal law: either by a federal statute or rule, or by "the principles of the common law as they may be interpreted by the courts of the United States in the light of reason and experience." 21 A general physician-patient privilege did not exist at common law, nor is it established by any federal statute or rule; therefore under Rule 26 it is commonly assumed to be unavailable in federal criminal cases. ${ }^{22}$ Two commentators have suggested that, whatever the legal theory, in federal criminal trials district judges often apply the privilege rules of the state in which they are sitting. ${ }^{23}$ This practice may often save a privilege in states where it exists, but uncertainty that any privilege will be preserved largely nullifies any incentive such a privilege may give anyone seeking medical help for drug-related problems. Change is clearly appropriate if a treatment and rehabilitation approach is to be tried.

The revised draft of the Proposed Rules of Evidence would delete, from both the Federal Rules of Civil Procedure ${ }^{24}$ and the Federal Rules of Criminal Procedure, ${ }^{25}$ all reference to the evidentiary rules, substituting uniform Federal Rules of Evidence to be applied in all federal courts

1936 Fed. Reg. 6075 (1971) (to be codified at 21 C.F.R. § 130.44).

20 FED. R. CIv. P. 43(a).

21 Fed. R. CRIM. P. 26.

22 E.g., C. DeWrtt, Privieged Comanunications Between Physictan and PATIENT 9-10, 78-79 (1958).

23 Korn, Continuing Effect of State Rules of Evidence in the Federal Courts, 48 F.R.D. 65, 66 (1969); Weinstein, The Uniformity-Conformity Dilemma Facing Draftsmen of Federal Rules of Evidence, 69 CoLum. L. Rev. 353, $371-72$ (1969).

24 See 51 F.R.D. 315, 470 (1971) (Proposed Amendments to the Federal Rules of Civil Procedure, rule 43).

${ }^{25}$ See id. at 472 (Proposed Amendments to the Federal Rules of Criminal Procedure, rule 26 ). 
in criminal, civil, and other cases. ${ }^{26}$ Article $V$ of the proposed rules, covering privileges, contains no general doctor-patient testimonial privilege, recognizing instead only a psychotherapist-patient privilege. ${ }^{27}$ In criminal prosecutions for federal drug abuse offenses, enactment of these provisions will often enable the prosecution to subpoena a physician and compel him to testify about incriminating confidential communications received from a defendant-patient. ${ }^{28}$ Thus, if the proposed Federal Rules of Evidence are adopted without change, a user of illegal drugs who consults a physician about medical problems will be taking some risk that the information he communicates to the physician will subsequently be introduced in support of a prosecution for violation of the federal drug laws, even if the confidentiality of the communications would be fully protected in any state prosecution.

There is no published evidence that the advisory committee which drafted the proposed Federal Rules of Evidence ever considered the impact of its rules concerning testimonial privileges on the medical treatment of drug abusers. The Committee was essentially directed to draft rules that would be uniform, and they apparently accepted this direction without questioning the desirability of uniform rules in criminal cases. ${ }^{29}$

The Advisory Committee concluded that the physician-patient privilege should not be one of the uniform rules. The Committee's notes offer only brief justification for this position. The single substantive argument advanced by the Committee is that

the exceptions [to a general privilege] which have been found necessary [by many states] in order to obtain information required by the public interest or to avoid fraud are so numerous as to leave little if any basis for the privilege. ${ }^{30}$

This comment reflects the fact that some states have never adopted the privilege and others have created exceptions to a general privilege statute for various proceedings. ${ }^{31}$ California, for example, excepts all

26 See Revised Proposed Rules, supra note 17, rule 1101, 51 F.R.D. at 462.

27 Id., rules 501, 504, 51 F.R.D. 351, at 366.

28 See note 4 supra. The physician's testimony would be admissible under a wellrecognized exception to the hearsay rule. See C. MCCORMICK, EvIDENCE \$266, at 563-64 (1954); ReVISEd Proposed Rules, supra note 17, rule 803(4), 51 F.R.D. at 419.

29 See 30 F.R.D. 73 (1962) (Preliminary Committee Report); Cleary, The Plan for the Adoption of Rules of Evidence for United States District Courts, 25 Record oF N.Y.C.B.A. 142, 144 (1970).

30 Revised Proposed Rules, supra note 17, 51 F.R.D. at 367 (Advisory Committee's Note to rule 504). Other arguments were premised on the absence of a privilege in federal criminal cases, and thus assume the point in issue here.

31 For a survey of state physician-patient privilege statutes, see C. DEWITT, supra note 22 , at $447-71$. 
criminal proceedings from the operation of the privilege. ${ }^{32}$ In states without a privilege or with very broad exceptions to it a federal privilege broader than that of the state would do little to encourage drug users to seek medical help, since the drug laws overlap and few users could safely assume that a case against them would not be brought in state courts. Other states do maintain a viable doctor-patient privilege, however, and the Advisory Committee's notes ignore the possibility of impeding the effectiveness of such state rules by adopting a contrary federal rule.

From the absence of any lengthy justification in the Advisory Committee's notes one may suspect that the drafters of the proposed Federal Rules were heavily influenced by various evidence scholars who have long called for the abolition of the physician-patient privilege. ${ }^{33}$ These scholars have doubted the empirical validity of the essential justification for a privilege: that it is needed to encourage a patient to disclose all aspects of his ailments so that his doctor can better treat him. They have asserted that most patients willingly divulge information about their medical condition to their doctors, even without the guarantee of a testimonial privilege, because typically patients do not weigh the potential consequences of future litigation in deciding whether to consult physicians. ${ }^{34}$ These scholars further point to the many instances in which the privilege has been invoked to prevent disclosure of reliable but adverse communications not made with the understanding that they would be kept confidential. Such instances frequently occur in health and disability insurance and personal injury cases wherein the plaintiff seeks to prevent introduction of medical reports contrary to his interests. ${ }^{35}$ Because of such abuses, McCormick has concluded that "the privilege in the main operates not as the shield of privacy but as the protector of fraud." 36

But even though one may not question that in the usual situation patients do not think about potential litigation consequences when deciding whether to consult a doctor, and that consequently the lack of a testimonial privilege should have no effect on their willingness to

32 CaL. Evid. Code $\$ 998$ (West 1966).

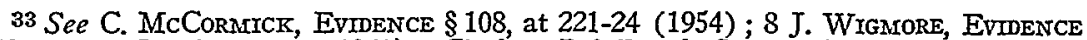
$\$ 2380 \mathrm{a}$ (McNaughton rev. 1961); Chafee, Privileged Communications: Is Justice Served or Obstructed by Closing the Doctor's Mouth on the Witness Stand?, 52 YAIE I.J. 607 (1943); Morgan, Suggested Remedy for Obstructions to Expert Testimony by Rules of Evidence, 10 U. CHI. L. Rev. 285, 290-91 (1943).

${ }^{34}$ See, e.g., Morgan, supra note 33, at 291.

${ }^{35}$ See Weinstock, Physician-Patient Privilege: Problems in Life and Health Insurance Litigation, 5 FORUM 37 (1969); sources cited note 33 supra.

36 C. MCCormick, Evidence § 108, at 224 (1954). 
do so, ${ }^{37}$ this assumption cannot properly be made for drug abusers. The experiences of physicians who have made concentrated efforts to treat drug abusers indicate that many are deterred from seeking medical assistance by fear of legal consequences. ${ }^{38}$ The growth of many lay organizations, such as "acid rescue leagues," to treat drug-related medical problems probably reflects similar fears. Because in most of these situations the fear of legal consequences may have resulted from the practice of many physicians and hospitals of reporting drug users to the police, it is not certain that the absence of a testimonial privilege (which is applicable only in court) would by itself deter requests for medical assistance. Certainly, however, the contrary assertion cannot be supported. Moreover, the evidence documenting the suspicious attitudes of many drug users towards establishment individuals and institutions ${ }^{39}$ strongly suggests that at least some drug abusers fear that their communications would be used against them in court. This inference has been reinforced, for me, by my experiences at the University of Wisconsin in discussing the legal implications of drug use with students and in helping a group of medical students establish a hybrid clinic and referral service patronized in part by drug abusers. These experiences revealed a strong interest by drug users in the legal implications of their conduct.

True, factors peculiar to federal prosecutions militate against the argument that an absence of a federal physician-patient privilege for drug abusers will deter requests for needed medical assistance. Even though the present law of evidence applicable to federal criminal trials may already fail to recognize a testimonial privilege for physician-patient communications, ${ }^{40}$ there has not so far been large scale manifestation of concern about this fact, either at the University of Wisconsin or, to my knowledge, elsewhere. One may assert that this is because the threat of federal prosecution is small since federal enforcement officials today

37 See, e.g., Morgan, supra note 33 , at 291 :

Nor is there any objective evidence that the existence of the privilege has had any influence in promoting public health or that its absence has had an adverse influence. . No one has had the temerity to assert that progress in medical science in England, in Maryland, in Massachusetts has been deterred in the slightest degree by their adherence to the common law rule, or that the development of the science and art of healing has been advanced in any measure in any state by the presence of the privilege. In short, there is nothing to demonstrate any benefit to the public in the privilege, while the law books are full of instances where its application has prevented the discovery of the truth to the damage of honest litigants.

38 See note 15 supra \& accompanying text.

39 Id.

40 See Wolfle v. United States, 291 U.S. 7 (1934) ; Taylor v. Reo Motors, Inc., 275 F.2d 699 (10th Cir. 1960); FED. R. CRIM. P. 26; Orfield, The Reform of Federal Criminal Evidence, 32 F.R.D. 121 (1963); Weinstein, supra note 23, at 377-95 (Appendix by Paul Sherman). 
are almost solely interested in convicting large volume distributors of illegal drugs, leaving it to the states to enforce laws against users. ${ }^{41}$ It is even more unlikely that federal officials would prosecute a drug user on the basis of communications he made to a physician, because the charge at both the state and federal level against most drug users is possession, not use, of illegal drugs, and because the prosecution's principal evidence usually is that the defendant possessed the drugs at the time of his arrest. It might be contended, therefore, that the absence of a federal privilege does not and should not discourage users of illegal drugs from consulting physicians.

Difficulties, however, do arise with denying a federal privilege. In the first place, the existing law is far from clear about the status of a testimonial privilege in federal courts; the ambiguity may vitiate any deterrence to seeking medical aid which a clear denial of the privilege would effect. Codified in an explicit way, the law will probably become known and more strongly deter medical requests by drug abusers, who are becoming increasingly sophisticated about their legal rights. Secondly, the contention fails to recognize that many drug users, particularly residents of drug subcultures in which the medical problems are probably most severe, are highly suspicious of the motives of police, federal prosecutors, and most doctors and hospitals. Because federal prosecution of users is technically possible, and users are becoming increasingly sophisticated in the law, a substantial number of such persons are likely simply to disbelieve assurances that despite the law there is no risk of federal prosecution based on communications made to physicians. The argument here is not, of course, that all drug users, or perhaps even any, will perceive the risk of prosecution as so great that they will never seek medical assistance for medical problems, no matter how serious. But a significant risk arises that, even if other deterring laws are unchanged, a federal rule of no-privilege will deter some drug users from requesting medical assistance in situations when such assistance is advisable.

The question of including a physician-patient privilege in the federal rules basically turns on weighing the desirability of encouraging drug users to consult physicians against the desirability of having all relevant evidence presented in federal prosecutions for violation of the drug laws. The latter goal is often cited in justifications of the existing federal law that apparently fails to recognize state privileges in federal criminal prosecutions. ${ }^{42}$ Today this goal ought not be given great

41 See CrIMe Contror Digest, Oct. 23, 1970, at 4-7. Federal law, though, prohibits possession and use of dangerous drugs as well as more serious offenses such as selling. See, e.g. Comprehensive Drug Abuse Prevention and Control Act of 1970, 21 U.S.C.A. $\$ \$ 841-51$ (Supp. 1971).

42 See, e.g., Revised Proposed Rules, supra note 17, 51 F.R.D. at 367 (Advisory Committee's Note to rule 504). 
weight in considering a rule regarding the confidentiality of physicianpatient communications about drug abuse. First, as already noted, federal enforcement officials are interested chiefly in prosecuting largevolume sellers of illicit drugs, even though mere possession and use remain violations of federal law. It is highly unlikely that relevant information could be obtained in such prosecutions from physicians, partly because most large-volume sellers are not users and therefore have no drug-related reason to consult a doctor, and partly because even a userdistributor who saw a doctor about his own abuse problem would have no reason to communicate confidential information about illicit sales operations. Consequently, a federal privilege is unlikely to hinder those prosecutions of drug law violators that federal enforcement officials are likely to initiate. Secondly, in the rare case in which there is a federal prosecution of a mere user, the change in overall federal drug policy from an exclusively punitive approach to one also emphasizing treatment and rehabilitation justifies impeding potential prosecutions of drug users. Admittedly, a treatment-and-rehabilitation approach to drug abuse problems remains largely untested in this country, but our long and unhappy experience with an exclusively punitive approach ${ }^{43}$ surely should support a policy of giving new approaches towards mere users every possible chance to succeed. Finally, it is highly unlikely that a physician-patient privilege will impede seriously the successful prosecution of illegal drug users. Even today such prosecutions almost never rest on communications made to physicians. ${ }^{4.4}$

A final consideration in weighing the desirability of a federal privilege for drug abusers is the potential impact on investigations by enforcement officials of drug law violations. Although federal officials rarely prosecute drug users, they sometimes use information provided by users to trace dealers. Pursuant to such an investigative approach federal officials might ask some physicians to reveal the names of drug users they have treated so that the users could be interrogated about their source of supply. Although the testimonial privilege would not technically prevent voluntary cooperation by physicians and hospitalssince the privilege applies only to in-court testimony-its existence would probably make voluntary reporting less likely. The effectiveness of the privilege aside, the investigative needs of the federal officials do not justify its negation. My conversations with one federal enforcement official and with numerous physicians have failed to reveal a single instance in which federal officials have adopted this investigative strategy. Moreover, it is unlikely that an investigative strategy will

43 See W. ErdRmGE, supra note 1.

44 Text following note 41 supra. 
ever be used regularly by federal enforcement officials: it would soon deter all drug users from contacting physicians except in circumstances of very serious illness, ${ }^{45}$ and once a deterrent effect took hold, enforcement officials would uncover few leads. Simultaneously, any hope for successful implementation of a treatment-and-rehabilitation approach to drug abuse would cease. Since enforcement officials might adopt this investigative strategy, a proposal for a federal physician-patient privilege at least poses a potential conflict between two important goals of existing federal policy towards drug abuse: prosecution of dealers in illicit drugs and rehabilitation of users of illegal drugs. My own biases lead me to favor the rehabilitation goal in the event of conflict. But even if the other goal is favored, the utility of an investigative approach that asks physicians to identify patients using drugs is so problematic that a privilege should be established at least until it can be shown to hinder significantly the detection and prosecution of large volume dealers.

I conclude, therefore, that a proper balancing of the needs of our varying approaches to the drug abuse problem supports the establishment of some form of physician-patient privilege applicable in the federal courts. Although a rule of no-privilege might deter a large number of requests for medical assistance, the interests that would be impeded by a privilege are insubstantial. The question then becomes how specifically to frame the privilege. One might contend that the psychotherapist-patient privilege in the proposed Federal Rules ${ }^{46}$ is broad enough to cover drug abuse cases. The definition of psychotherapist includes "a person authorized to practice medicine. . . who devotes all or a part of his time to the practice of psychiatry, or is reasonably believed by the patient so to be." ${ }^{47}$ A patient is defined as "a person who consults or is examined or interviewed by a psychotherapist for purposes of diagnosis or treatment of his mental or emotional condition." 48 This limited privilege would permit a group of psychiatrists to establish a clinic catering to the mental and emotional problems of

45 See note 15 supra.

46 Revised Proposed Rules, supra note 17, 51 F.R.D. at 315.

47 Id., rule 504(a) (2) (i), 51 F.R.D. at 366. Rule 504(a) (2) (ii) also includes licensed clinical psychologists as psychotherapists for purposes of this rule.

The preliminary draft of the proposed rules limited the definition of psychotherapist to a doctor who devotes "a substantial portion" of his time to the practice of psychiatry. Proposed Rules of Evidence for the United States District Courts AND MAGistrates rule 5-04(a) (2) (Preliminary Draft, 1969), in 46 F.R.D. 161, 257 (1969). The revised draft affords the protection of the privilege to a much larger proportion of drug counseling by physicians.

48 Revised Proposed Rules, rule 504(a) (1), supra note 17, 51 F.R.D. at 366 (emphasis added). This Article discusses only the need for a physician-patient privilege for communications concerning drug abuse. There are other medical problems, such as venereal disease, which people will be reluctant to discuss with a physician unless confidentiality is assured. A federal testimonial privilege for communications concerning these problems might also be granted. 
drug users and guarantee their clients confidentiality. Moreover, since the treatment of drug abusers frequently involves counseling in connection with their underlying psychological problems, an argument might be made that any doctor who treats drug abusers "devotes . . . a part of his time to the practice of psychiatry" and that his patients are "examined or interviewed" (at least in part) "for purposes of diagnosis or treatment of [their] mental or emotional condition." These possibilities alone, however, will not avoid the deleterious effects of the proposed Federal Rules on the willingness of drug abusers to seek medical assistance. In the first place, where the drug abusers seeks assistance for a purely medical problem, such as poisoning from impure drugs or inflammation of the veins, it is difficult to stretch the definition of patient to provide a privilege. More importantly, to be encouraged successfully to make use of physicians, a drug user highly suspicious of doctors and law enforcement officials needs a guarantee that his communications will remain confidential, not merely an arguable legal defense to their use in a subsequent criminal prosecution.

It appears, consequently, that the proposed Federal Rules need amendment. The arguments I have made do not support a general privilege because for many types of physician-patient communications the dangers that the privilege will be invoked for fraudulent purposes may outweigh any dangers of deterrence to the disclosure of ailments to a physician. A privilege should be granted, however, for those types of communications, such as ones concerning drug abuse, for which the case for a privilege is strongest. Many states have provided a privilege with exceptions for communications concerning acts with regard to which the public interest in having evidence revealed in court is considered particularly strong-for instance, communications which reveal child abuse. $^{40}$ What I am suggesting here is that this approach be stood on its head. The federal rules of evidence might omit a general physicianpatient privilege but grant it in certain limited circumstances.

Iowa has recently enacted a statute which apparently takes this approach. That act protects communications to medical practitioners made by any person requesting "treatment and rehabilitation for [drug] addiction or dependency." "50 The statute, however, does not define "addiction," "dependency," "treatment," or "rehabilitation," and consequently it is unclear whether only some drug abusers seeking medical assistance are protected by the privilege. 51 The failure to define "treat-

49 See C. DEWITT, supra note 22 , at $447-71$.

50 Iowa CodE ANN. \$\$224A.2-3 (Supp. 1971).

51 In medical circles the term "addiction" is disfavored, and all habitual use of drugs is defined as "dependence," which can be physical, psychological, or both. See Eddy et al., Drug Dependence: Its Significance and Characteristics, 32 Buld. of WHO 721 (1965); Seevers, Psychopharmacological Elements of Drug Dependence, 
ment" and "rehabilitation" leaves open the possibility that the privilege does not protect all drug dependent persons requesting medical treatment, but rather only those persons requesting assistance in ceasing a drug dependency. The use of the phrase "treatment and rehabilitation" in some sections of the statute cannot be relied upon as an interpretative tool, since in the same sections the phrase "treatment or rehabilitation" also appears, without any evident reason for changing conjunctions. Restricting the privilege to those seeking to eliminate a dependency, as is thus at least feasible, would have the advantage of limiting the privilege to circumstances in which the case for a treatment approach to drug abuse problems, and for overriding any law-enforcement interest in omitting the privilege, is strongest. On the other hand, it continues to deter requests for medical assistance in circumstances in which a user needs medical assistance (for example, in dealing with the effects of a bad trip) but does not desire to cease using drugs.

As previously indicated, the different focus of federal law makes it unlikely that a broader federal privilege will significantly hinder federal law enforcement. And, I trust, few persons regard illegal drug use as such a serious crime that we should attempt to deter it by making one of its costs the unavailability of medical assistance for serious, drug-related medical problems. Consequently, at least pending a stronger case that a privilege will hinder law enforcement, the privilege should be extended to all requests for medical assistance in connection with use of illegal drugs. The Iowa statute is not a good model for a federal rule.

The approach just suggested might be criticized on the ground that protecting the confidentiality of communications regarding drug abuse serves little purpose if the communications are made in those states which will not respect their confidentiality in criminal proceedings. ${ }^{52}$ An answer to this objection is that granting a uniform privilege in federal courts for such communications probably will little hinder federal investigations and prosecutions. If this objection is nevertheless considered weighty, ${ }^{53}$ then the proposed Federal Rules might be

206 J.A.M.A. 1263 (1968). The concept of dependence is not, however, so precise as to make easy the classification of drug users as either "dependent" or "not dependent." This imprecision of the Iowa statute may deter drug abusers from seeking medical assistance, thus vitiating the statute's intended effect.

52 See C. DEWITT, supra note 22 , at 447-71.

53 The possibility of forum shopping in civil suits is the major objection to a federal rule different from the state rule. But the decision to adopt uniform federal rules of evidence indicates that the forum-shopping objection has not been weighted heavily. If a federal privilege were limited largely to criminal proceedings, forum shopping in the usual sense cannot be involved. A discrepancy between the state and the federal rule of privilege might, however, influence the decision whether to prosecute under state or federal law. 
amended to provide that a state physician-patient privilege shall govern with regard to communications concerning drug abuse, but only when the state privilege is broader than the privilege otherwise recognized by the federal rules.

Admittedly such an approach would be inconsistent with the goal of uniformity for federal rules of evidence. Before the Chief Justice of the United States appointed the present drafting committee, he first appointed, in 1960, a Special Committee on Evidence to consider the advisability and feasibility of developing uniform rules of evidence for the federal courts. That Committee reported that uniform rules were both desirable and feasible, and on its recommendation the present Advisory Committee was appointed to prepare such rules. The principal justification for uniform rules given by the Special Committee rested on the complexity of the existing rules of evidence. It noted that although the federal courts were authorized to create their own rules of evidence in criminal, admiralty, and bankruptcy cases, no systematic and understandable body of case law had been developed. The situation in many states was as bad or worse. The result, the Committee noted, was that inconsistent decisions were often reached in cases purportedly governed by the same law. It concluded that if the Supreme Court were to promulgate uniform rules of evidence for federal courts, evidence decisions in federal courts would be made more easily and more rationally, and the states might be encouraged to simplify and rationalize their own evidence laws. ${ }^{54}$

Although recognition of a state physician-patient privilege broader than the privilege provided by the proposed Federal Rules of Evidence would impinge somewhat on a policy of uniformity, I do not believe that it would seriously undercut the principal justifications that have been offered for a policy of uniformity. So long as the number of provisions in the Federal Rules dependent on state law is limited, the rules will not become unduly complex. ${ }^{55}$ Nor do I believe that such a provision would impinge on the goal of providing the states with an example of sensible evidentiary rules that they can copy. At a minimum, it would seem, sufficient doubt has been cast on the wisdom of denying a physician-patient privilege for communications regarding drug abuse to undercut any argument that the federal government should encourage the states to deny the privilege.

54 Preliminary Study of the Advisability and Feasibility of Developing Uniform Rules of Evidence for the Federal Courts, 30 F.R.D. 73 (1962); see Estes, The Need for Uniform Rules of Evidence in the Federal Courts, 24 F.R.D. 331 (1960).

55 Proposed rule 502, 51 F.R.D. at 360 , already provides for limited variation between states, in recognizing the privileged character of reports required by law, when the requiring law also provides for their confidentiality. 
My conviction on this point is strengthened by considerations of federalism, which are largely ignored in the proposed rules with their single-minded concern for uniformity. Indeed, concern with federalism has led several renowned evidence scholars to question whether in diversity cases the Federal Rules should, or can constitutionally, ignore testimonial privileges established by the state in which the case is heard, or, depending on the applicable conflict-of-law rules, in which the communication was made..$^{56}$ These scholars have suggested that a state's interest in fostering certain interpersonal relationships by providing for testimonial privileges should be respected in the absence of any overriding federal interest. In federal criminal cases, however, federalism has usually not been advanced as a reason to question seriously a policy of uniformity in evidentiary rules. ${ }^{57}$ Following two Supreme Court decisions rendered in the early 1930's holding that evidentiary questions in federal criminal cases were to be determined according to federal law, ${ }^{58}$ it has been assumed that the federal interest in ascertaining the truth in prosecutions for transgression of its laws outweighs any state interest in avoiding federal infringement of its policy of fostering certain interpersonal relationships by creating testimonial privileges. Given the seriousness of the growing drug abuse problem, however, a state's decision, as part of an overall treatment-andrehabilitation approach, to encourage drug abusers to contact physicians by providing protection for confidential communications is worthy of respect. And the federal interest in prosecutions for violations of its drug abuse laws is smallest in those cases in which the privilege is most likely to become a relevant issue-prosecutions for possession or use of illicit drugs. ${ }^{59}$

56 C. Wright, Federal Courts 409-15 (2d ed. 1970); Degnan, The Laze of Federal Evidence Reform, 76 HARv. L. REv. 275, 287-301 (1962); Weinstein, supra note 23, at 370-73. See also Louisell, Confidentiality, Conformity and Confusion: Privileges in Federal Courts Today, 31 TuL. L. Rev. 101 (1956).

57 But see Weinstein, supra note 23, at 370-72.

58 Wolfle v. United States, 291 U.S. 7 (1934) ; Funk v. United States, 290 U.S. 371 (1933).

59 One final objection to a privilege for physician-patient communications regarding drug abuse is that as proposed here it would be applicable not only in criminal trials, but in civil proceedings, such as personal injury suits or actions on insurance policies, as well. Misuse of the privilege in such civil proceedings has caused much of the current agitation to abolish the privilege. See notes 33-36 supra \& accompanying text. If it is thought necessary to limit a privilege for communications concerning drug abuse so that it is inapplicable to personal injury suits, actions on insurance policies, and perhaps a few other civil actions, such a limitation would be unlikely to deter significantly the willingness of drug users to request medical assistance. Care should be taken in delimiting the civil proceedings to be included in the exception, however, because of the existence of involuntary civil commitment proceedings for narcotics addicts in federal courts. See Narcotic Addict Rehabilitation Act of 1966, 42 U.S.C. $\$ \$ 3411-26$ (Supp. V, 1970); Aronowitz, Civil Commitment of Narcotic Addicts, 67 CoLuM. L. REV. 405 (1967). Narcotics addicts contemplating requesting 
Finally, it should be noted that there is still time to incorporate the suggestions made in this Article in the Federal Rules of Evidence before they are officially adopted. The revised draft of the proposed rules, which is the version that has been discussed in this Article, was approved by the Judicial Conference of the United States in October 1970 and then submitted to the Supreme Court for consideration and promulgation. In March 1971 the Supreme Court returned the revised draft to the Committee on Rules of Practice and Procedure of the Judicial Conference for further consideration, ${ }^{60}$ and that Committee has indicated that it will entertain comments and suggestions from the profession until August 1, 1971. Presumably sometime thereafter the Judicial Conference will resubmit the rules to the Supreme Court, perhaps with some revisions of the present draft. If the Court approves and promulgates the rules, they will become effective ninety days thereafter, unless in the interim Congress alters their provisions or remands them to the Court for further consideration. ${ }^{61}$

\section{B. Limiting Investigatory Power Under the Controlled Substances Act}

The second aspect of federal law potentially jeopardizing the confidentiality of physician-patient communications is the scope of the investigatory powers granted the Attorney General in the recently enacted omnibus revision of the federal drug control laws. ${ }^{62}$ Two provisions of the Controlled Substances Act could be interpreted to give the Attorney General the power to demand access to records containing information communicated confidentially by a drug user to a physician or to hospital personnel. The first would authorize the Attorney General, in the course of investigations

relating to his functions under this title with respect to controlled substances ... [to] subpena witnesses, compel the attendance and testimony of witnesses, and require the production of any records . . . which the Attorney General finds relevant or material to the investigation. ${ }^{63}$

medical assistance would probably fear involuntary commitment nearly as much as criminal confinement. On the other hand, the government may have a stronger interest in having physician-patient communications available for involuntary commitment proceedings than for criminal prosecutions or law enforcement investigations.

60 See Letter from Albert B. Maris to the Bench \& Bar, March 15, 1971, in 51 F.R.D. 316.

6118 U.S.C. $\$ 3771$ (Supp. V, 1970) ; 28 U.S.C. \$2072 (Supp. V, 1970). A copy of this Article was submitted to the Committee during preparation for publication.

62 Comprehensive Drug Abuse Prevention and Control Act of 1970, Pub. L. No. 91-513, 84 Stat. 1236 (codified at 21 U.S.C.A. \$\$ 801-966 (Supp. 1971)). Title II of this Act, 21 U.S.C.A. $\$ \$ 801-904$ (Supp. 1971), is called the Controlled Substances Act.

63 Controlled Substances Act $\$ 506($ a), 21 U.S.C.A. \$876(a) (Supp. 1971). 
This provision makes no mention of any testimonial privileges that would be recognized in such investigations, although obviously the self-incrimination privilege would be recognized. Perhaps, by interpretation, the doctor-patient privilege would be recognized as well, although this result seems highly unlikely if the Federal Rules of Evidence fail to provide for a privilege in federal criminal cases.

The second provision potentially providing the Attorney General access to confidential information allows the issuance of administrative inspection warrants which would authorize inspections by the Attorney General of "controlled premises," defined by the Act in such a manner as to include many doctors' offices and nearly all hospitals. ${ }^{\text {fi }}$ Such a warrant issues whenever the judge or magistrate finds there is "a valid public interest in the effective enforcement of this title or regulations thereunder sufficient to justify administrative inspections of the area . . . " 65 Unless the warrant indicates otherwise, the Attorney General may then inspect "all . . . things . . . (including records, files, papers, processes, controls, and facilities) appropriate for verification of the records, reports, and documents [required by the Act ] . . . or otherwise bearing on the provisions of this title . . . ."66 Certain matters, including financial and pricing data, are specifically exempted from this general power to inspect, ${ }^{67}$ and omission of confidential information regarding patients from this list suggests an exemption for such information could not be carved out by interpretation.

64 Id. $\$ 510$ (a), 21 U.S.C.A. $\$ 880$ (a) (Supp. 1971). A third power given the Attorney General authorizes him to "inspect the establishment of a registrant or applicant for registration in accordance with the rules and regulations promulgated by him." Controlled Substances Act $\$ 302$ (f), 21 U.S.C.A. § 822(f) (Supp. 1971). Since essentially all doctors and hospitals are required to register under the Act, on its face this section gives the Attorney General the broadest possible investigatory power. It is doubtful, however, that the provision should be so interpreted, for to do so would render meaningless the procedures painstakingly delineated in the section authorizing administrative inspections and warrants. See note 66 infra. More likely $\$ 302$ (f) will be used only for inspections at the time of initial registration; nevertheless, at this time as at any other, there is a need to protect the confidentiality of physician-patient communications at that time.

$65 I d$. $\$ 510$ (d) (1), 21 U.S.C.A. $\$ 880$ (d) (1) (Supp. 1971).

${ }^{66}$ Id. $\$ 510$ (b) (3) (B), 21 U.S.C.A. $\$ 880$ (b) (3) (B) (Supp. 1971). Section 510 (d) (2), 21 U.S.C.A. \$ 880 (d) (2) (Supp. 1971), provides that a warrant must identify "the area, premises, building, or conveyance to be inspected, the purpose of such inspection, and, where appropriate, the type of property to be inspected, if any." The issuing magistrate can therefore restrict the inspection to deny access to confidential physician-patient communications. Typically, however, issuers of search warrants merely approve the wording proposed by the applicant. Applicants for administrative inspection warrants will probably seek the widest possible inspections of controlled premises.

${ }^{67} I d . \$ 510$ (b) (4), 21 U.S.C.A. $\$ 880$ (b) (4) (Supp. 1971). The Bureau of Narcotics and Dangerous Drugs, however, in response to a request from the American Medical Association, has indicated that it is considering exempting medical diagnosis and therapy records from administrative inspections. 36 Fed. Reg. 7777 (1971) (Comments and Objections to Part 316, No. 1). 
The investigatory powers granted the Attorney General by these two provisions in the omnibus revision of the federal drug control laws contain many of the same infirmities as the proposed Federal Rules of Evidence. Even assuming these investigatory powers will be interpreted to entitle the Attorney General to compel testimony about, or to gain access to records reflecting, confidential physician-patient communications, the Act would not by itself permit the introduction into court of this information. Nevertheless, there is a serious risk that the possible availability of such information to the Attorney General will convince many prospective patients, if they become aware of the Attorney General's powers, that by communicating incriminating information to the physician, they could become the focus of a subsequent investigation. During this investigation admissible incriminating information might be uncovered. Alternatively, the investigation might uncover the patient's illegal drug source, and that source is frequently a friend.

It is somewhat ironic that the Act provides the Attorney General with investigatory powers that could have this deterrent effect, for there is no indication of a legislative intent to permit the Attorney General to jeopardize the confidentiality of communications between doctor and patient. The structure of the Act implies that the primary purpose in authorizing the Attorney General to hold administrative hearings for which he can subpoena witnesses and records was to give him a means to acquire the information he needs to place controlled substances in different classifications established by the Act ${ }^{68}$ and to set quotas on the legitimate production of certain classifications of controlled substances. ${ }^{69}$ There is no suggestion in the legislative history that the Attorney General was to use administrative hearings to gain information on which to base prosecutions for illegal use or sale of controlled drugs, yet section 505(a) clearly authorizes the subpoena of patient files for administrative hearings. And access to confidential physician-patient communications would most clearly aid the Attorney General in hearings with this latter objective.

Similarly, the scheme of the Act indicates that the primary purpose of authorizing the Attorney General to conduct administrative inspec-

68 See Controlled Substances Act $\$ \$ 201-02,21$ U.S.C.A. \$\$811-12 (Supp. 1971).

69 See id. $\$ 306,21$ U.S.C.A. $\$ 826$ (Supp. 1971). In the original bill, title V was called Offenses and Penalties, title VI (containing the hearing section) was called Administrative Provisions, and title VII was called Enforcement Provisions, implying a separation of the hearing power from the enforcement powers. See S. 2637, 91st Cong., 1st Sess. (1969). In the bill's final form, title IV was moved back to become subchapter II, and titles VI and VII were combined as part E, with no changes in the order or content of the individual sections. See H.R. 18,583, 91st Cong., $2 d$ Sess. (1970). 
tions was to provide him with a means to verify the reports and records that the Act requires of persons authorized to manufacture, distribute, or dispense certain controlled substances. ${ }^{70}$ In the overwhelming majority of circumstances the Attorney General could adequately verify the required reports and records without access to confidential physicianpatient records. ${ }^{71}$ But the language of the Act permits administrative inspections of all things located on controlled premises "appropriate for verification" of records required by the Act "or otherwise bearing on the provisions of this title . . ."72 And other provisions of the title establish criminal penalties for the illegal possession or sale of controlled substances. ${ }^{73}$

Further indication that Congress did not intend the Attorney General to jeopardize the confidentiality of physician-patient communications is provided by two discretionary provisions in the Act which specifically protect communication in limited circumstances. One provision imposes a duty on all federal agencies and instrumentalities, when so requested, to assist the Attorney General in enforcing the Act. ${ }^{74}$ Contained in the Administration's original version of the Act, ${ }^{75}$ this provision was lengthened by Congress to provide also that no such agency "shall be required to furnish the name of, or other identifying information about, a patient or research subject whose identity it has

70 See Controlled Substances Act $\$ \S 302-03,307,21$ U.S.C.A. $\$ \$ 822-23,827$ (Supp. 1971). The Act authorizes administrative inspections only of "controlled premises," which will include the offices of some, but not all, doctors who treat drug abusers. See id. \$510, 21 U.S.C.A. \$ 880 (Supp. 1971). Had Congress intended the administrative inspections to give the Attorney General access to all files on drug abuse patients, it could have so provided; but as the Act stands, the presence of patient records on controlled premises is only a coincidence of which Congress indicated no intention to take advantage.

71 Many doctors are exempted from recordkeeping requirements (although their premises are still defined as "controlled premises" for purposes of the administrative inspection warrant provision). Controlled Substances Act $\$ 307(\mathrm{c}), 21$ U.S.C.A. $\$ 827$ (c) (Supp. 1971). Where doctors and hospitals are required to keep records, basically they must show only how a controlled substance was distributed or dispersed. Id. $\$ 307$ (a), 21 U.S.C.A. \$827(a) (Supp. 1971). The Act specifically permits a registrant to maintain the records required by the Act separate from his other records. Id. $\$ 307$ (b) (2) (A), 21 U.S.C.A. $\$ 827(\mathrm{~b})(2)(\mathrm{A})$.

$72 I d . \$ 510$ (b) (3) (B), 21 U.S.C.A. $\$ 880$ (b) (3) (B) (Supp. 1971).

73 See id. part D, 21 U.S.C.A. $\$ \$ 841-51$ (Supp. 1971). There may, of course, be constitutional objections to permitting an administrative inspection to be used to collect evidence on which a criminal prosecution can be based. The standard of probable cause provided in the Act for issuance of an administrative inspection warrant is less stringent than that required for a search warrant. A less stringent standard may be constitutional so long as the purpose of the administrative inspection is limited to verification of required reports and records. See Camara v. Municipal Court, 387 U.S. 523 (1967) ; See v. City of Seattle, 387 U.S. 541 (1967). If an administrative inspection has a different purpose, however, traditional standards of probable cause may be required.

74 Controlled Substances Act $\$ 503$ (b), 21 U.S.C.A. $\$ 873$ (b) (Supp. 1971).

75 H.R. 13,742, 91st Cong., 1st Sess. $\$ 603$ (b) (1969) ; S. 2637, 91st Cong., 1st Sess. $\$ 603$ (b) (1969). 
undertaken to keep confidential." 76 This section could be interpreted to foreclose access by the Attorney General, under his investigatory powers, to records held by a federal agency of confidential doctor-patient communications it did not wish to divulge. ${ }^{77}$ The other provision originally appeared in the Administration's bill ${ }^{78}$ and was approved by Congress without substantial change. It permits the Attorney General to "authorize persons engaged in research to withhold the names and other identifying characteristics of . . . subjects of such research," and persons so authorized cannot be compelled to reveal such information in any state or federal proceeding, including the Attorney General's investigatory proceedings. ${ }^{79}$ A final indication of congressional intent is contained in an extensive amendment to the bill passed by the Senate which would have established a vastly expanded rehabilitation program for drug abusers. ${ }^{80}$ One part of this amendment would have stringently protected physician-patient communications relating to drug abuse in both state and federal proceedings. ${ }^{81}$ The entire rehabilitation amendment, including the confidentiality provision, was deleted by the conference committee. The conference report made no mention of the confidentiality issue, justifying the deletion on the ground that the House had not had an opportunity to hold hearings on the extensive, government-financed rehabilitation program. ${ }^{82}$

76 Controlled Substances Act $\$ 503$ (b), 21 U.S.C.A. $\$ 873(\mathrm{~b})$ (Supp. 1971). The amendment was approved by voice vote. 116 Cong. REc. 1335, 1336 (1970).

77 The Act furnishes no definition of federal "agency or instrumentality," leaving open the possibility that a hospital receiving federal financial assistance could be considered a federal agency or instrumentality for purposes of this section.

78 S. 2637, 91st Cong., 1st Sess. $\$ 602$ (c) (1969).

79 Controlled Substances Act $\$ 502$ (c), 21 U.S.C.A. $\$ 872$ (c) (Supp. 1971).

80 S. Amdr. No. 1003 to H.R. 18,583, 91st Cong., 2d Sess. (1970).

81 Id. $\$ 132(b)$ :

(b) All patient records and all information contained therein relating to drug abuse or drug dependence prepared or obtained by a private practitioner shall remain confidential, and may be disclosed only with the patient's consent and only to medical personnel for purposes of diagnosis and treatment of the patient or to Government or other officials for the purpose of obtaining benefits due the patient as a result of his drug dependence.

82 Conf. Rep. No. 1603, 91st Cong., 2d Sess. (1970), in 1970 U.S. Code Cong. \& AD. NEws 4657, 4658. For the legislative history of the entire Act, including this amendment, see CoNG. Q. WEEKLY REP., Oct. 16, 1970, at 2539-42.

The efforts of the National Committee for Effective Drug Abuse Legislation, a lobbying group composed of doctors, lawyers, and scientists, suggest that the confidentiality problems of the Act were brought to Congress' attention. That Committee characterized the Attorney General's investigatory powers as "placing in jeopardy the confidentiality of the patient's record . . . Committee for Effective Drug Abuse Legislation, Pending Drug Abuse Legislation: Fact Sheet, on file in Biddle Law Library, Univ. of Pa. Law School. How much significance should be attached to the Committee's failure to win changes in the Attorney General's investigatory powers is not clear. The Committee was most concerned with securing the transfer to the Secretary of Health, Education and Welfare some of the powers given to the Attorney General in the Administration's bill, and it may be that the Committee did not press their objections to the Attorney General's investigatory powers sufficiently to bring them to the attention of the key members of Congress. 
In view of this legislative history it is possible that the Attorney General's investigatory powers will not be interpreted to include access to confidential physician-patient communications. The language of the Act, however, cannot be easily reconciled with such an interpretation. Consequently, unless courts restrict the Attorney General's investigatory powers, the Act will probably deter requests for medical assistance for drug-related medical problems, at least if a significant portion of the drug-taking community acquires knowledge of the Act's provisions pertaining to investigatory powers. The most obvious means of avoiding this deterrent effect is to amend the federal drug laws quickly so that the Attorney General's investigatory powers clearly do not permit him to compel testimony about confidential physician-patient communications or to gain access to records thereof. A more expeditious alternative, but one less satisfactory given the suspicious attitudes of many drug users, would be for the Attorney General to announce that he will not attempt to use his investigatory powers to compel testimony about confidential physician-patient communications or to gain access to records thereof.

\section{Methadone Maintenance Programs}

The third aspect of federal law deals with the legal problems of methadone maintenance programs for heroin addicts. Under these programs, which exist in most large cities, heroin addicts are given daily doses of methadone. Methadone, a synthetic, addicting opiate, is said to block the action of heroin, eliminate the craving that drives many former addicts to resume use of the drug, and produce neither euphoria nor distortion of behavior. It is an addicting drug, however. The treatment goal of methadone maintenance programs, therefore, is to draw the addict out of the illegal drug subculture and away from a life of crime and to help him cope productively with his new environment. Having realized these objectives, many programs try to end the patient's methadone dependence by gradually reducing the daily dosage. ${ }^{83}$

Although methadone has other recognized medical uses, the Food and Drug Administration (FDA) has taken the position that with regard to methadone as a maintenance drug there is not yet available "substantial evidence of long-term safety and effectiveness . . . under the Federal Food, Drug and Cosmetic Act standards for the general marketability of new drugs." 84 Nevertheless, the use of methadone as a maintenance drug can qualify for the investigational exemption to the new-

83 See generally Cole, supra note 1; Note, Methadone Maintenance for Heroin Addicts, 78 Y YLE L.J. 1175 (1969).

8436 Fed. Reg. 6075 (1971) (codified at 21 C.F.R. $\$ 130.44$ (a)); see 21 U.S.C. \$355 (1964); id. \$321(p) (Supp. V, 1970); 21 C.F.R. §130.1(h)(5) (1971). 
drug approval requirement. ${ }^{85}$ A recent FDA regulation states that to qualify for an investigational exemption, the sponsor of the methadone maintenance program must obtain the approval of both the FDA and the Bureau of Narcotics and Dangerous Drugs. To obtain this approval the sponsor must file a protocol describing in detail the contemplated procedures for his maintenance program and must assure, among other things, that records "of all observations and other data pertinent to the investigation on each individual treated" are maintained and made available for inspection by authorized FDA agents. The regulation further provides: "The Bureau of Narcotics and Dangerous Drugs is also authorized to inspect these records under the Harrison Narcotic Act." 88

When a substantially similar FDA regulation was proposed earlier, ${ }^{87}$ it provoked objection to many of its provisions, including the requirement that records be made available for inspection. ${ }^{88}$ The usual ground for objection to the latter requirement was that it constituted an unjustified invasion of the confidential relationship between doctor and patient. ${ }^{89}$ In terms of the particular concerns of this Article, the recordkeeping and inspection requirements could have especially unfortunate effects. Almost every entrant into a methadone maintenance program is a recent user of heroin. He is therefore a potential subject of federal or state prosecution, or, perhaps more likely, of an intimidating and unpleasant interrogation by law enforcement personnel to elicit his source of supply. It is reasonable to expect, consequently, that some prospective participants will be deterred from joining a methadone program by fear of revelation of even their identities and certainly of their medical histories as the FDA regulation allows.

In issuing the final regulation without significant change in the recordkeeping and inspections requirements contained in the proposed rule, Commissioner Edwards of the FDA attempted to justify the availability of records to FDA personnel by noting that reports of adverse reaction to long-term intake of methadone may require identification of other patients, presumably to warn them of possible similar adverse effects. ${ }^{90}$ But FDA regulations regarding other new drug

8521 U.S.C. $\$ 355$ (i) (1964).

8636 Fed. Reg. 6077 (1971) (to be codified at 21 C.F.R. $\$ 130.44(d)$ ). The Bureau of Narcotics and Dangerous Drugs, revising a long held position that the prescription or administration of narcotics in a way maintaining addiction violated federal drug laws, now recognizes the legality of methadone maintenance programs receiving a new drug investigational exemption from the Food and Drug Administration. 36 Fed. Reg. 6081 (1971) (to be codified at 26 C.F.R. \$151.411); see Note, Methadone Maintenance for Heroin Addicts, supra note 83.

8735 Fed. Reg. 9014 (1970).

8836 Fed. Reg. 6075 (1971).

89 Id.

$90 I d$. 
investigations, although generally requiring that records of the investigation be available for FDA inspection, specifically provide that " $[t]$ he names of the [patients] need not be divulged . . . ." except in special circumstances. $^{91}$ In these cases the FDA apparently believes that, when adverse reactions are reported, notification to the investigators, usually physicians, dispensing the drug is sufficient to channel the necessary information to the research subjects. No justification was offered for treating methadone maintenance investigations differently.

The statement in the FDA regulations that the Bureau of Narcotics and Dangerous Drugs is authorized to inspect these records under the Harrison Narcotic Act is only partly correct and in one respect quite misleading. The Harrison Narcotic Act did require physicians dispensing narcotics, such as methadone, to maintain records showing the amount dispensed, the date, and the name and address of the patient, and to make these records available for inspection by the Bureau of Narcotics and Dangerous Drugs. ${ }^{92}$ Apparently, however, there was an exception if the physician directly administered the narcotic, a procedure used in many methadone programs. ${ }^{93}$ Moreover, that Act did not require a physician to maintain and make available for inspection other records such as medical histories, although the FDA regulation so implies. The FDA regulation is also misleading in that although the Harrison Narcotic Act was in effect when the regulation became effective, April 2, 1971, it was replaced on May 1, $1971,{ }^{94}$ with the Controlled Substances Act, ${ }^{95}$ which differs in relevant respects. Specifically, a physician now need not maintain records with regard to the prescribing or administering of certain narcotics, including methadone, "in the lawful course of his professional practice." 96 Addi-

9121 C.F.R. $\$ 130.3(\mathrm{a})(12)(6)(\mathrm{e})$ (1971); see id. $\$ 130.3(\mathrm{a})(13)(4)(\mathrm{e})$. The special circumstances are when "the records of the particular subjects require a more detailed study of the cases, or [when] there is reason to believe that the records do not represent actual studies or do not represent actual results obtained." Id. \$130.3 (a) (12) (6) (e).

92 Act of Aug. 16, 1954, ch. 736, 68A Stat. 551, 567 (repealed 1971). The Bureau of Narcotics was transferred from the Treasury Department to the Justice Department in 1968. 33 Fed. Reg. 5611 (1968).

93 Act of Aug. 16, 1954, ch. 736, 68A Stat. 551 (repealed 1971) ("except such as may be dispensed. . . to a patient upon whom such physician... shall personally attend ....").

94 See Comprehensive Drug Abuse Prevention and Control Act of $1970 \S \S 1101$ (b) (3), 1105(a), Pub. L. No. 91-513, 84 Stat. 1292, 1295. (1970).

95 See Controlled Substances Act $\$ 704(a)$, Pub. L. No. 91-513, 84 Stat. 1284

96 Controlled Substances Act $\$ 307$ (c) (1) (A), 21 U.S.C.A. $\$ 827$ (c) (1) (A) (Supp. 1971). A recent regulation requires that the physician maintain records, including the names of recipients, with respect to such narcotics if he dispenses them "other than by prescribing or administering." 36 Fed. Reg. 7790, 7793 (1971) (to be codified at 21 C.F.R. $\$ \$ 304.03(\mathrm{~b}), 304.24$ (d)). This requirement may include the dispensing of narcotics directly to recipients for self-administration, such as commonly occurs in methadone maintenance programs. Cf. Controlled Substances Act $\$ 307$ (c) (1) (B), 21 U.S.C.A. \$827(c) (1) (B) (Supp. 1971). 
tionally, as noted previously, the Attorney General can now authorize persons engaged in research to withhold the names of research subjects, and a person so authorized cannot be compelled to reveal such information in any proceeding, presumably including one conducted by the FDA. ${ }^{97}$ The FDA regulation failed to discuss these provisions of the Controlled Substances Act, which were then soon to be and are now the applicable law.

If it is considered desirable to remove the infringement imposed by the FDA regulation on doctor-patient confidentiality within methadone maintenance programs, the only effective remedy is either to convince the Attorney General to authorize the withholding of names under the provision just noted, or to enact legislation. ${ }^{98}$ The FDA Commissioner, although not compelled to require that records identifying methadone program participants be maintained and held available for inspection, was apparently acting within his delegated powers in doing so. ${ }^{92}$ The case for confidentiality is nevertheless strong. Methadone maintenance is generally recognized as one of the most promising methods available for treating heroin addicts. Moreover, the risk that the FDA regulation will dissuade some addicts from participating in such programs cannot be discounted on the ground that programs have operated for several years without ironclad assurances of confidentiality. Certain types of addicts-for example, those who believe they are not known by the police as heroin users-may be deterred even if others are not, and these addicts may be the most susceptible to rehabilitation through methadone maintenance. Particularly given the research goals the FDA imposes on methadone programs, it would seem unfortunate to discount this possibility until there is convincing evidence that the recordkeeping aspects of the FDA regulation have no serious impact on the willingness of heroin addicts to accept methadone treatment.

There are, of course, costs to law enforcement in guaranteeing confidentiality. If, however, law enforcement officials were to prosecute participants in maintenance programs for past heroin use, or even to interrogate them about past sources of supply, the deterrent to participation could be almost total. This law-enforcement interest must be sacrificed, therefore, unless treatment- and rehabilitation-objectives are

97 See 21 U.S.C.A. $\$ 872$ (c) (Supp. 1971); text accompanying note 79 supra.

9S Even if the Controlled Substances Act were interpreted so as not to provide the Bureau of Narcotics and Dangerous Drugs direct access to the records of a methadone maintenance program, there would be nothing to prevent the Food and Drug Administration, which clearly would have access to these records, from forwarding them to the Bureau.

${ }^{99}$ See 21 U.S.C. $\$ 355$ (i) (3) (1964). But see id. $\$ 355(\mathrm{j})$ (1) (1964) ("regulations and orders issued. . under subsection (i) . . shall have due regard for the professional ethics of the medical profession and the interests of patients ...."). 
to be substantially foregone. A more realistic law enforcement interest in access to the names of participants is preventing diversion of methadone into illegal markets. There are other techniques for limiting diversion possibilities, however. For example, the FDA regulation already lists in its "suggested" protocol for methadone maintenance programs a statement that a program will conduct frequent urine checks on participants to insure against continued heroin usage. ${ }^{100}$ This control, if administered properly, prevents a participant from continuing his heroin use while diverting his entire methadone allotment into the illegal market in order to raise money to purchase heroin. Reliance should be put on controls like these, which do not jeopardize confidentiality, until there is reason to believe they are not being administered properly or for some other reason are not preventing the illegal diversion of methadone. Then, perhaps, but only then, should the FDA and the Bureau of Narcotics and Dangerous Drugs have access to the names of program participants. ${ }^{101}$

\section{State Law}

Many changes could be made in the laws of the various states to buttress the confidentiality of physician-patient relationships. The changes discussed here are those that, on the basis of my own involvement in this area, seem the most important ones common to a number of states.

\section{A. Physician-Patient Privilege in State Courts}

Perhaps the most visible need for change in state law is for the establishment or broadening of a testimonial privilege for physicianpatient communications. Several states have no doctor-patient privilege at all, and others have created exceptions so broad that the privilege is essentially unavailable to the patient with medical problems related to drug abuse. ${ }^{102}$ Even in states with a broad doctor-patient privilege, ambiguities about its scope may remain. For example, in Wisconsin

10036 Fed. Reg. 6077 (1971) (to be codified at 21 C.F.R. $\$ 130.44$ (c) (6) (E) (2)). The FDA regulation imposes numerous other controls with similar objectives on methadone maintenance programs. Indeed, one purpose of requiring prior approval by the Bureau of Narcotics and Dangerous Drugs of proposed methadone programs is to insure that the contemplated procedures will "prevent diversion of [methadone] into illicit channels ...." Id. 6075 (to be codified at 21 C.F.R. $\$ 130.44$ ).

101 The scheme proposed here, therefore, would resemble the record-availability requirements that the FDA imposes on most other new drug investigations. See note 91 supra \& accompanying text. These procedures should also be sufficient to protect FDA's access to accurate information about the medical results of a methadone maintenance program so that it can evaluate the safety and effectiveness of methadone maintenance for treating heroin addiction.

102 See C. DEWIrr, supra note 22, at 447-71. 
it is unclear whether the privilege applies to communications made to, or in the presence of, auxiliary medical personnel, such as nurses, medical students, and technicians. ${ }^{103}$ There seems no basis for treating auxiliary medical personnel operating under the direction of a physician differently from the physician himself, and legislation should be enacted in these states to ensure that result, at least when it regards a drug abuse problem. ${ }^{104}$

If a state presently does not protect the confidentiality of physicianpatient communications concerning drug abuse, the question whether a privilege should be provided is more difficult. A decision to permit a privilege seems the wiser choice because a rehabilitation approach offers more promise for a long-term solution to drug abuse problems than does the long-tried law-enforcement approach, and the potential impediment to effective law enforcement posed by the privilege should be a cost worth bearing. But if a state retains a strong commitment to a law-enforcement approach, then the effect of a privilege on law enforcement becomes important, for the states more commonly undertake activity directed at illegal drug users than does the federal government. The extent to which a privilege would impede the successful prosecution of mere users is the major issue. ${ }^{105}$ Although there is no conclusive empirical evidence available on this issue, most prosecutions are for possession, not use, of illegal drugs. ${ }^{106}$ Thus it seems unlikely that prosecutions would be significantly affected. Also, because there are more prosecutions of drug users at the state than the federal level, omission of a physician-patient privilege at the state level is more likely to deter requests for medical assistance. If the decision whether to provide a privilege is to be made by balancing the needs of law-enforcement and rehabilitation approaches to drug abuse, therefore, the need for a rehabilitation approach seems to weigh more heavily.

103 See WIS. Stat. AnN. \$885.21 (1966); Prudential Ins. Co. v. Kozlowski, 226 Wis. 641,276 N.W. 300 (1938).

104 Another prevalent exception in state laws is embodied in UNIFORM NARCOTIC DRUG ACT $\$ 17(2)$ (1932): "Information communicated to a physician in an effort unlawfully to procure a narcotic drug, or unlawfully to procure the administration of any such drug, shall not be deemed a privileged communication." This exception may be a justifiable one, for without the testimony of physicians it would be nearly impossible for the state to enforce the law prohibiting acquisition of narcotic drugs in the manner indicated. Thus the state's interest in preventing concealment of the truth is much stronger than it is with regard to the ordinary narcotics offense, where the state has many ways other than from the testimony of physicians to collect the necessary evidence.

105 Perhaps consideration should also be given in such a state to the possible impact of a privilege on investigations of drug law violations by law-enforcement officials. A privilege may hinder efforts to obtain the voluntary cooperation of physicians in providing names of drug users, and state officials may be more inclined than federal officials to use this investigative strategy. Because of the impact on rehabilitation and treatment of drug abusers, however, on balance a privilege still seems desirable. See text accompanying notes 117-18 infra.

100 See text following note 41 supra. 
Determining how extensive to make a state privilege would involve considerations similar to those at the federal level. If a state is unwilling to provide a general physician-patient privilege because of a belief that such a broad privilege is too often abused in civil cases, a privilege could be established only for communications regarding drug abuse. If this limited privilege is to be any broader, its scope might be determined by considering whether the absence of a privilege for the particular communications is likely to deter resort to medical personnel. A limited privilege could be even further restricted so as not to apply in certain civil proceedings ${ }^{107}$ or even to apply only to communications by patients seeking medical assistance in stopping a drug habit, although as I have argued previously, the latter restriction is probably undesirable. ${ }^{108}$

Discussion of possible state testimonial privileges for physicianpatient communications should include discussion of the proposed Uniform Controlled Substances Act. Recently promulgated by the National Conference of Commissioners of Uniform State Laws, this statute is designed to make laws on narcotic and dangerous drug use more uniform and to harmonize them with the new federal Controlled Substances Act. ${ }^{109}$ Many of the provisions of the proposed Uniform Act are identical or quite similar to the federal law, including a provision authorizing the appropriate state officials to make administrative inspections of hospitals and most doctors' offices. ${ }^{110}$ One provision, however, which has no counterpart in the federal Act, deals directly with the question of a physician-patient privilege. It provides:

A practitioner engaged in medical practice or research is not required or compelled to furnish the name or identity of a patient or research subject to the [appropriate person or agency], nor may he be compelled in any State or local civil.

107 See note 59 supra.

108 Text accompanying and following notes 50-51 supra.

109 There is reason to believe that the statute was promulgated by the National Conference of Commissioners on Uniform State Laws at the urging of the Bureau of Narcotics and Dangerous Drugs. President Nixon announced about two years ago that the Department of Justice was drafting a model statute regulating narcotics and dangerous drugs. See 1969 Cong. Q. Almanac 57-A. To date, nothing has been published by the Department of Justice. The reporter for the committee which drafted the Uniform Controlled Substances Act, however, was Michael Sonnenreich, an employee of the Bureau of Narcotics and Dangerous Drugs.

110 Compare Uniform Controlled Substances Act $\$ 502$ (1970) with Controlled Substances Act $\$ 510,21$ U.S.C.A. $\$ 880$ (Supp. 1971). There is no provision for administrative hearings and subpoenas, presumably because the Uniform Act contemplates that state law will classify controlled substances by simply following the federal classifications. See UnIForm Controlled Substances AcT \&201 (1970). Nor does the Uniform Act suggest that a state set quotas on the manufacture of controlled substances. The federal Act provides for administrative hearings and subpoenas principally to facilitate acquisition of information as to which classification to assign a drug and what quotas to set for its manufacture. See notes 68-73 supra \& accompanying text. 
criminal, administrative, legislative or other proceedings to furnish the name or identity of an individual that the practitioner is obligated to keep confidential. ${ }^{111}$

For several reasons this provision is neither as clear nor as broad as I believe a privilege statute should be. First, "practitioner" is so defined in the proposed Uniform Act as to permit the interpretation that it does not apply to receptionists, some nurses, and other auxiliary medical personnel who become privy to confidential information while acting under the supervision of a practitioner. ${ }^{112}$ Secondly, technically the provision only protects the name or identity of the patient; the provision might be interpreted as inapplicable to other information about a patient, such as the drugs he used, the general area in which he lives, and so forth. The availability of this type of information could significantly deter resort to medical assistance, since some of the information could be used by law enforcement agencies to help identify the patient or close friends using drugs.

Thirdly, the privilege is limited to instances in which the practitioner is "obligated" to keep confidential the name or identity of a patient. The provision and the drafting committee's comments are silent as to whether "obligated" is limited to a statutory obligation or includes also an obligation resting on a professional or personal code of ethics. The former interpretation would render the need for this section merely preservative of established privilege statutes and so of arguable utility. On the other hand, another section of the proposed Uniform Act may be read to suggest that indeed only a statutory obligation will suffice. That section provides that researchers authorized by the appropriate person or agency cannot be compelled in legal proceedings to identify the individuals who are the subjects of research. ${ }^{113}$ Since the proposed Uniform Act includes within its definition of "practitioner" a "person . . . permitted to . . . conduct research with respect to . . . a controlled substance," 114 the section specifically protecting researchers is unnecessary if a nonstatutory code of ethics creates an obligation to respect confidentiality under the general privilege section, assuming any nonstatutory code would prevent authorized researchers from divulging subjects' names. Perhaps the sensible interpretation of the general privilege statute is to construe "obligated" to include nonstatutory, in-

111 UnIForm Controlled Substances Act \$ 504(c) (1970).

112 See id. $\S 101(t)$. In contrast, the Iowa statute previously referred to extends the privilege to a "medical practitioner or any employee or person acting under his direction . . . Iowa CODE ANN. \$224A.2 (Supp. 1971).

113 Uniforar Controlled Substances ACt $\$ 508$ (d) (1970).

114 Id. $\$ 101(\mathrm{t})$. 
stitutionally formulated codes of ethics, ${ }^{115}$ but not purely personal codes of ethics. Under such an interpretation a physician would be "obligated" by the code of ethics promulgated by a recognized medical association even if the state does not have a statutory physician-patient privilege.

Finally, the general privilege section only speaks of the practitioner not being compelled to testify. Most privileges also provide that the practitioner may not voluntarily testify without the patient's consent. If the omission of the latter provision is considered significant, then a physician not bound by a typical physician-patient privilege statute to respect confidential communications could testify even if he could not be compelled to do so. Since a patient often has no effective remedy if his physician violates a medical code of ethics by revealing confidential communications, ${ }^{116}$ this result could deter requests for medical assistance where, as with drug abuse, the consequences to the patient of revealing a confidential communication could be severe.

In short, if a state should seriously consider adoption of the proposed Uniform Controlled Substances Act-and it seems likely that many will-it should not rely on that statute for a physician-patient privilege regarding drug abuse. The only section mentioning a privilege is worded in an extremely confused manner, and indeed it may appear to protect confidential communications while in fact being but a saving clause for protections which already exist in a state in which the statute is enacted.

\section{B. Voluntary Reporting of Drug Abusers}

Perhaps the most needed change in state laws results because some physicians and hospitals voluntarily notify the police when approached by a drug user for treatment of a drug-related medical problem. Such conduct violates few state privilege statutes since those statutes usually apply solely to testimony in court and in other official proceedings. Nevertheless, such actions probably have a greater chilling effect on the willingness of drug users to seek medical assistance than any official conduct. $^{117}$ Voluntary reporting may cause the police to investigate a patient's activities and uncover sufficient evidence of illegal drug use to justify a criminal prosecution. More often, the doctor's notification subjects the patient to frightening and unpleasant interrogation by police officers attempting to discover the drug source.

115 Alternatively, a practitioner might be considered "obligated" to respect confidentiality only if a licensing statute requires him not to reveal professional secrets. See note 119 infra \& accompanying text.

116 But cf. notes 119-25 infra \& accompanying text.

117 See note 15 supra. 
If treatment and rehabilitation of drug abusers is to be emphasized at the state level, this particular deterrent to requesting medical assistance for drug-related medical problems should be removed. The mere existence of the problem, however, suggests that many state lawenforcement officials, unlike federal officials, have relied on information supplied by physicians, because the practice probably would not persist if the police failed to act on the information received or actively discouraged such communications. On the other hand, the substantial chilling effect of this practice on the willingness of drug abusers to seek medical assistance suggests that reliance on physicians for information about drug users is a self-defeating law-enforcement strategy: its principal effect will not be to provide law-enforcement officials with many names of drug users but to keep abusers away from physicians and hospitals-an effect seemingly perceived by many reporting doctors and hospitals. ${ }^{118}$ Accordingly, a state's commitment to law-enforcement solutions to the drug abuse problem should not be hindered by forbidding such reporting. If a state has any commitment at all to a treatment- and rehabilitation-approach to drug abuse, it should take measures to prevent physicians and hospitals from voluntarily communicating information about drug-using patients. Law-enforcement agencies would remain free to use other investigative techniques, such as informers, for learning the identity of drug-law violators, including those violators who request medical assistance.

There are a number of possible approaches to stopping this practice. The most satisfactory approach would be simply to educate physicians and hospitals about the undesirable consequences of such action and in this way persuade them to stop. With increasing emphasis, both within the medical profession and elsewhere, on treatment and rehabilitation of drug abusers, this approach has considerable promise. In Madison, Wisconsin, for example, one hospital which formerly often notified the police when a drug user came to the emergency room for treatment of a bad trip has recently been persuaded to change its practice.

Another approach is to encourage the victims of this practice to attempt legal action against the offending physician or hospital. To my knowledge, no drug abuser reported to the police after requesting medical treatment has brought suit against a physician or hospital, but if physicians and hospitals realized that such actions were a significant possibility, police notification might diminish quickly. There are several possible theories on which a drug abuser could proceed. 
Perhaps the most effective action against physicians is to initiate proceedings for suspension or revocation of their licenses to practice. Most states provide for suspension or revocation for "unprofessional conduct," or similarly defined behavior. The nature of such conduct is not always defined in the statutes. ${ }^{119}$ Since medical codes of ethics generally stress the importance of honoring the confidentiality of doctorpatient communications, however, it should be possible to convince a decisionmaker that unnecessarily revealing the identity of a patient is unprofessional conduct. State procedures for revoking medical licenses vary, of course, and it may be that in some states a victim of a physician's notification of the police can only file a complaint with the licensing agency. In Wisconsin, though, the statutes provide that the district attorney "shall" initiate action to revoke a doctor's license upon receiving a verified complaint that the doctor engaged in unprofessional conduct. ${ }^{120}$ This provision was interpreted by one of that state's attorneys general to impose a mandatory duty upon a district attorney to file suit when he receives a verified complaint. ${ }^{121}$

There are also several legal theories on which a physician or hospital wilfully betraying a professional confidence might be sued for damages. ${ }^{122}$ Any visit to a physician or hospital creates at least an implied contract to pay for the services received. In view of the emphasis on confidentiality in medical codes of ethics, a court might be convinced to imply as one term of that contract a promise not to reveal voluntarily a confidential communication. ${ }^{123}$ If the state has a statute explicitly providing for license revocation for violating professional

119 WIS. STAT. ANN. $\$ 448.18(1)$ (d) (1970) defines "immoral or unprofessional conduct" to include "wilfully betraying a professional secret." An identical statute has been interpreted very restrictively by one state. See McPheeters v. Board of Medical Examiners, 130 Cal. App. 297, 284 P. 938 (1930).

120 Wis. Stat. AnN. $\$ 448.18(2)$ (1970).

12125 Op. Atr'y GeN. Wis. 567 (1936).

122 Admittedly, there might be some difficulty in proving damages in these cases. Most of the actions which have been brought against physicians for betraying a professional secret have sought damages for mental anguish, loss of reputation, or some such intangible loss. See Carr v. Shifflette, 82 F.2d 874, 877 (D.C. Cir. 1936) (concurring opinion). Presumably some similar damages claim would have the best chance for success when the police have been informed of a patient's illegal drug use. Considerable mental anguish can result from a police interrogation-commonly the immediate consequence of a physician's notification to the police of a patient's illegal drug use-especially if the patient is on a "bad trip" at the time. See Madison Kaleidoscope, supra note 16. Though the problem of jury prejudice looms large, in a clear case a directed verdict may be possible.

123 See Hammonds v. Aetna Cas. \& Sur. Co., 243 F. Supp. 793 (N.D. Ohio 1965) ; Forbes, Professional Confidence, 13 Medico-llegar \& CRIminologrcal Rev. 18 (1945). One court, recognizing, a cause of action for betrayal of a confidential communication also recognized a limited immunity from liability if the communication was shown to have prevented the spread of contagious disease. Simonsen v. Swenson, 104 Neb. 224, 177 N.W. 831 (1920) ; see Berry v. Moench, 8 Utah 2d 191, 331 P.2d 814 (1958). Whether this immunity should be extended to include the reporting of 
secrets, then a damage action for violation of a statutory standard may be maintainable. ${ }^{124}$ Some opinions suggest a physician has a commonlaw duty not to reveal confidential communications unnecessarily and may be sued in tort in the event of breach. ${ }^{125}$

Still a third approach to this problem is to enact legislation prohibiting notification of police or others by physicians and hospitals. The recent Iowa law discussed above provides that physicians, hospitals, and auxiliary medical personnel

shall not report or disclose the name of such person [requesting treatment and rehabilitation for drug addiction or dependency] or the fact that treatment was requested or has been undertaken to any law enforcement officer or agency . . . . 126

Violation results in a fine, not exceeding one hundred dollars, or imprisonment not exceeding thirty days. ${ }^{127}$ Although the statute's object is salutary the penalty chosen is of questionable value. When a physician or hospital notifies the police, the information will often be welcomed by them and the prosecuting attorney, and criminal prosecution seems unlikely. Thus, a draftsman would be well advised to include a civil remedy for the victim of a statutory violation. ${ }^{123}$

\section{Physicians' Conflicting Loyalties}

A third needed change in state law results from a problem similar in some ways to the problem just discussed. Institutionally employed physicians are sometimes faced with conflicting obligations to their

criminal conduct to the police has never been litigated in a reported decision. $C f$. Aarerican Medical Ass's, Principles of Medical Exhics \$9 (1957):

A physician may not reveal the confidences entrusted to him in the course of medical attendance, or the deficiencies he may observe in the character of patients . . . unless he is required to do so by law or unless it becomes necessary in order to protect the welfare of the individual or of the community.

124 See Simonsen v. Swenson, 104 Neb. 224, 177 N.W. 831 (1920).

125 See Hammonds v. Aetna Cas. \& Sur. Co., 243 F. Supp. 793 (N.D. Ohio 1965) ; Smith v. Driscoll, 94 Wash. 441, 162 P. 572 (1917). In Hanmonds it was also suggested that the relationship between doctor and patient is analogous to a fiduciary relationship and that a betrayal of confidential communications would be a breach of that "fiduciary" duty for which an action could be maintained. $243 \mathrm{~F}$. Supp. at 802 .

Invasion of privacy, where the state recognizes such a tort, is another possible theory. Barber v. Time, 348 Mo. 1199, 159 S.W.2d 291 (1942); DeMay v. Roberts, 46 Mich. 160, 9 N.W. 146 (1881); cf. Berry v. Moench, 8 Utah 2d 191, 331 P.2d 814 (1958).

126 Iowa CoDE ANN. §224A.2 (Supp. 1971); see id. \$224A.3.

127 Id. \$224A.6.

128 In providing a civil remedy, it would be desirable to set a minimum recovery by statute. In many situations compensatory damages may be difficult to prove and jury prejudice difficult to overcome, note 122 supra, and absent a minimum recovery provision a statute might not have the desired deterrent effect. 
employers and to their patients. Examples of physicians in such circumstances are company physicians, if the company's employees are permitted to consult them about personal medical problems, and physicians employed by student health centers at universities. There is some confusion within the medical profession as to whether such physicians are ethically bound to honor the confidentiality of patient communications if the information revealed is desired by the physicians' employers. ${ }^{129}$ Obviously, if information that a patient is using illegal drugs is communicated to a physician's employer, it can result in dismissal of an employee or disciplinary action against a student. As a result, if the physician is known to report such information to his employer, prospective patients will be deterred from consulting the physician about drug-related medical problems.

For essentially the same reasons that physicians should be prohibited from notifying the police when approached by drug users, it would be desirable policy to require institutionally employed physicians to refrain from notifying their employers of drug-related communications made to them. Such a policy would not prevent employers and universities from detecting violations of their rules in other ways, and might encourage more drug abusers to seek medical assistance. Fortunately, this viewpoint is being adopted voluntarily, particularly at universities. At the University of Wisconsin, for example, the student health center, with the blessing of the university administration, never relays drug-related information communicated in confidence by a patient either to the police or to university authority. The policies at some universities, however, may be less salutary. For example, a pamphlet published by the California Institute of Technology in 1969 promises confidentiality for disclosures made to health center personnel and specifically states that "information disclosed to Health Center personnel . . . will not be available to be used in any way as the basis for any disciplinary or administrative action." 130 Two paragraphs later, however, the pamphlet observes:

In case of serious drug effects, the Health Center will be concerned, as it is with any serious medical condition, in determining what course of action will best serve the student's

129 See Willig, Legal Rights of Employees, Physician and Company, in DRuG Abuse IN INDUSTRY 65 (W. Stewart ed. 1970); Smith, Physician's Duty to Patient - to Company, in id. 81. One commentator argues that no confidentiality obligation arises if the physician is merely investigating on behalf of a third person (for instance, a medical test required as part of a job application), but that an obligation does arise if the physician begins advising or treating the patient. C. DEWrTT, supra note 22, at 114-16. Obviously this distinction is not always easily applied.

130 California Institute of Technology, Drugs and the Caltech Student 28 (1969) (student information pamphlet). 
own interests and will minimize the risk of future mentalhealth difficulties. For this reason, any student who is hospitalized for treatment of drug effects will be readmitted to the Institute only after certification by the Student Health Center that the individual appears to be fully recovered and capable of performing Institute work normally. Students who are not hospitalized but who, in the judgment of the Director of Health Services, are unable to perform satisfactorily because of the effects of drug use may be placed on either voluntary or involuntary medical leave from the Institute, subject to return under the same conditions as following a hospitalization..$^{131}$

If informal approaches are not successful in establishing the confidentiality of drug-related information communicated to an institutionally employed physician, other remedies should be sought. The patient might be able to use some of the remedies suggested above if a physician contacted the police. ${ }^{132}$ The conflicting loyalties of the physician, however, make less clear the physician's obligation under existing law not to convey the information, and consequently courts may be reluctant to uphold such a cause of action. ${ }^{133}$ The other possible solution, of course, is legislation to prohibit communication of information pertaining to drug abuse to anyone, including the physician's employer, if it is obtained in the context of a physician-patient relationship.

\section{Parental Consent}

The final needed state-law change to be discussed here derives from the special legal problems that confront a physician when a minor requests medical attention. To avoid an action for battery, a physician or hospital must, whenever possible, obtain the consent of the patient to the treatment proposed. ${ }^{134}$ If the patient is a minor, statutorily disabled from consenting, the parent or guardian must consent. ${ }^{135}$ Yet many under-age drug abusers very much desire that information about their drug abuse not be communicated to their parents. Often, a physician will resolve this conflict by neglecting to obtain the parent's

131 Id. 29.

132 See notes $122-25$ supra \& accompanying text.

133 Some cases have allowed a physician a limited privilege to reveal confidential communications. See sources cited in note 123 supra.

$13 \pm$ See W. Prosser, Torts \$18, at 104 (3d ed. 1964).

135 B. Shartel \& M. Plant, The Law of Medical Practice 25-26 (1959). See also Comment, Informed Consent as a Theory of Medical Liability, 1970 WIS. L. REv. 879; Note, Restructuring Informed Consent: Legal Therapy for the DoctorPatient Relationship, 79 YALE L.J. 1533 (1970). 
consent, particularly if the indicated medical treatment is routine. ${ }^{136}$ Most physicians, even in university-sponsored student health centers, however, will either notify the parents if the medical situation becomes complicated, ${ }^{\mathbf{1 3 7}}$ or refuse to treat a minor patient beyond a certain point unless he obtains parental consent. To the extent this policy is known, it can only operate to deter minor drug abusers from seeking medical assistance for drug-related problems.

An obvious solution to this problem is to enact legislation making legally effective a minor's consent to treatment for drug-related medical problems. Iowa, again setting an example, has done something similar by providing that a minor can give effective legal authorization for treatment and rehabilitation of drug addiction or dependency. ${ }^{138}$ Massachusetts has recently enacted a similar law. ${ }^{139}$ A few other states have enacted statutes which permit minors to consent to treatment for other medical problems, such as pregnancy or venereal disease, about which minors often prefer their parents not learn. ${ }^{140}$ Objections will probably be made that such legislation interferes with a parent's relationship with his child and prevents the parent from helping to resolve the social and emotional problems that typically accompany such medical problems. If the knowledge that a physician may convey confidential communications to a minor's parents deters minors from seeking medical assistance, however, failure to enact consent legislation will result both in parents' remaining in ignorance of their children's problems, and thus disabled from providing social and emotional guidance, and in minors' not receiving important medical assistance. For these reasons, statutes authorizing minors to consent to treatment for drugrelated problems are eminently sensible, and other states ought to adopt them.

136 Cf. Bakker v. Welsh, 144 Mich. 632, 108 N.W. 94 (1906).

137 See California Institute of Technology, supra note 130, at 28 :

In the case of a minor student, Health Center authorities may sometimes have a responsibility to notify parents if they consider this necessary, but even this step will not be taken without the student's permission unless the situation

is such that the Health Center authorities feel they have no alternative.

Despite its reassuring tone, the equivocation of this sentence is astounding on careful reading.

138 Iowa CODE ANN. \$224A.2 (Supp. 1971). The same section provides explicitly that the physician shall not inform the minor's parents about the minor's drug addiction or dependency without his consent. Criminal sanctions are provided for violation of this prohibition. Id. $\$ 224 \mathrm{~A} .6$.

139 Mass. AnN. LAws ch. 112, §12E (Supp. 1971) (legalizing consent to treatment by minor found "drug dependent" by two physicians).

140 See Ird. ANN. Stat. ch. 91, \$§18.1, 18.4, 18.5 (Smith-Hurd Supp. 1970) (minor may consent to treatment of pregnancy or venereal disease, but parents may be notified); MD. ANN. CoDe art. 43, $\$ 135$ (1971) (same, but if pregnancy or venereal disease is not diagnosed, parents may not be notified). 


\section{CONCLUSION}

A law-enforcement approach to drug abuse problems is no longer perceived as the sole or even necessarily the best approach to solving the problems such activity presents society. Because it is based upon a deterrent approach to deviant behavior, the operation of such a scheme tends to cause offenders to avoid situations which may lead to detection of their behavior by potentially disapproving authorities, such as police and employers.

If a treatment-and-rehabilitation approach is to be given a fair chance, laws with such deterrent effects must at least not depend on the cooperation of those attempting to treat the offender. Implicit in the recognition of a treatment approach is toleration of drug use when recourse to treatment or rehabilitation is attempted. The legal changes suggested in this Article will not solve the entire drug-abuse problem, but they may reduce a major impediment to the success of an approach which holds a great deal of promise. 